\title{
Investigating the potential of using human movements in energy harvesting by installing piezoelectric tiles in Egyptian public facilities
}

\author{
Madonna Makram Solban and Rania Rushdy Moussa* \\ Department of Architecture Engineering, The British University in Egypt (BUE), El-Sherouk City, 11837, Egypt \\ *Corresponding Author : Rania.Rushdy@bue.edu.eg
}

$\begin{array}{ll}\text { Submitted } & : 08 / 01 / 2020 \\ \text { Revised } & : 31 / 03 / 2021 \\ \text { Accepted } & : 12 / 04 / 2021\end{array}$

\begin{abstract}
Developing countries are facing huge challenges toward energy production. Energy crisis not only negatively affects the industry, agricultural, commercial, and residential sectors, but it also negatively affects the development of these countries. Relying on renewable energy sources is one of the methods used to tackle the energy problem. The increase in energy costs produced from fossil fuel and the decreasing in fossil fuel production helps in decreasing the gap between the cost of energy generated from renewables and fossil fuel. Using the human population density in generating energy from renewable piezoelectric tiles in public facilities is the aim of this research. The presented research intends to investigate the potential of replacing the floor tiles in public facilities with piezoelectric tiles to generate energy and benefit from the high human population density and movements inside these facilities, and people will start to produce nonstop energy from walking throughout the facility. The presented research used quantitative method to investigate the potential of replacing the floor tiles in Shobra El-Khema metro station with piezoelectric tiles toward energy production. The research compared the electricity generated from piezoelectric tiles with the electricity consumed to electrify the station. According to the population density in Shobra El-Khema metro station, the research revealed that installing 7 Waynergy tiles in a location where all the station passengers are passing through will generate $3990 \mathrm{KW}$, which will electrify the station.
\end{abstract}

Keywords: Electricity generation; Floor tiles; Piezoelectric tiles; Sustainable metro station.

\section{INTRODUCTION}

In recent years, the interest in harvesting vibration energy using piezoelectric materials has increased rapidly, and it attracted a great deal of attention. Many researchers studied different application for energy harvesting in general and piezoelectric tiles specific such as Anton \& Sodano, 2007; Mak, et al., 2011; Shwehdi, et al., 2015; Moussa, 2017, Moussa, 2018; Rawat and Vadhera, 2019; Vinod \& Sinha, 2019; Moussa, 2020. 

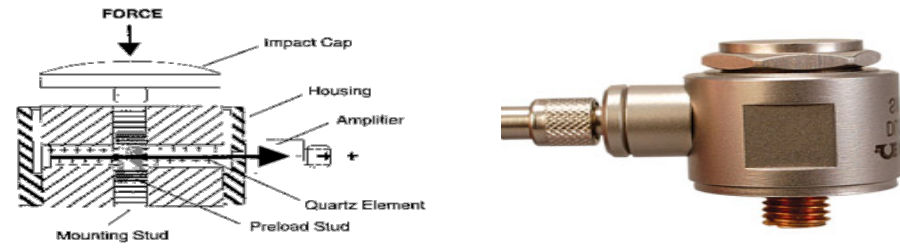

Figure 1. Piezoelectric cells (Omega, 2016).

Previous research states that Energy harvesters from roads and transport systems are noteworthy which this research intends to prove otherwise. Unfortunately, there are still economic, environmental and social challenges that stand against the usefulness of harvesting energy form piezoelectric sources. This challenge is concentrating on concerns about environmental damage and climate change, which could be caused from increasing the thermal microclimate of roads and transportation sector. In fact, energy harvesting from roads is a clean source of efficient energy and environmental conservation. Solar, vibration, acoustic waves are the types of energy sources that can be harvested from roads and transportation systems. Piezoelectric materials are crystals that produce power when compressed or vibrated as shown in figure 1.

Piezoelectric cells fall inside a class of various solid-state materials that can create power with the use of some boost, for example, heat, stress, or light (Hill, Agarwal and Tong, 2014). Piezoelectric gadgets inserted in roadways may recover energy as vibration and pressure under the vehicle tires (Hill, Agarwal and Tong, 2014). Utilizing piezoelectric to reap vibration energy from people strolling, apparatus vibrating, or vehicles moving on a roadway is intriguing, as it is a clean and not expensive energy (Hill, Agarwal and Tong, 2014).

Piezoelectric materials creating a voltage about $210 \mathrm{~V}$, but the material is not accessible yet (Rahman et al., 2012; Solban \& Moussa, 2019). Piezoelectric energy transformation creates moderately higher voltage and power contrasted with the electromagnetic framework (Rahman et al., 2012; Moussa, 2019).

Piezoelectric materials produce extremely small quantities of electricity; however, an artificial piezoelectric material such as PZT generates more electricity (Moussa, 2020). According to East Japan Railway, an average person weighing $60 \mathrm{~kg}$ will generate only 0.1 watt in the single second required to take two steps across the tile, but when the piezoelectric tiles are covering a large area of floor space and thousands of people are stepping or jumping on them, then significant amount of power can be generated as shown in figure 2 (Shreeshayana et al., 2017; Sunithamani et al., 2017).

This research intends to highlight the importance of using piezoelectric tiles toward energy generating. Generating clean energy for public facilities using the movements of people inside the facilities is the scoop of this research. The main aim of this research is to use piezoelectric tiles in designing the interior flooring of public facilities, in which it will electrify the facility with clean source of energy as well as it will protect the environment from global problems and reduce the carbon emissions in developing countries such as Egypt. 


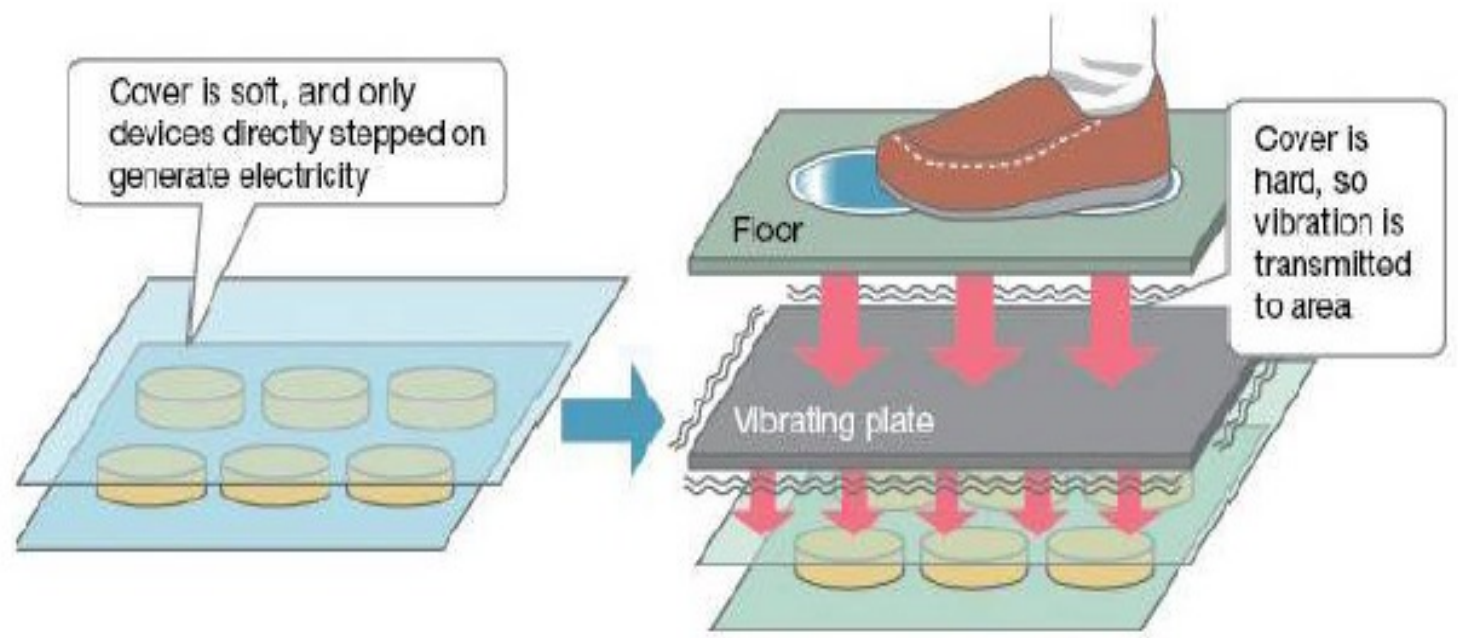

Figure 2. Flooring Tiles with Piezoelectric Crystals (Shreeshayana et al., 2017).

\section{THE FRAMEWORK OF PIEZOELECTRIC TILES}

According to previous research and marketing websites, the presented research summarized the properties of different types of piezoelectric tiles as presented in Table 1 (Energy Floors, 2019; Pavegen, 2019; Power generation bed, 2019; Elhalwagy et al., 2017; Mishra et al., 2015; Farahat, 2014; Balouchi, 2013; Bischur and Schwesinger, 2012; Rodrigues et al., 2011; Starner and Paradiso, 2003; Kachapi, 2019; Kachapi, 2020).

Table 1. Piezoelectric technology types main technical specifications, price and lifespan.

\begin{tabular}{|c|l|c|c|c|c|}
\hline \multicolumn{2}{|c|}{ Company } & Tiles Size & Energy produced & Price & $\begin{array}{c}\text { Estimated } \\
\text { lifespan }\end{array}$ \\
\hline 1 & Waynergy Floor & $40 \times 40 \mathrm{~cm}$ & $10 \mathrm{~W}$ per step & $451.5 \$$ & 20 years \\
\hline 2 & $\begin{array}{l}\text { Sustainable Energy floor } \\
\text { (SEF) }\end{array}$ & $\begin{array}{c}75 \times 75 \mathrm{~cm} \\
\text { OR } \\
50 \mathrm{~cm} \text { tile }\end{array}$ & $\begin{array}{c}\text { Up to } 30 \text { watt of } \\
\text { continuous output. Typical } \\
\text { power output for } \\
\text { continuous stepping by a } \\
\text { person lies between } 1 \text { and } \\
10 \text { W nominal output per } \\
\text { module (average } 7 \mathrm{~W})\end{array}$ & $1,693 \$$ & 15 years \\
\hline
\end{tabular}




\begin{tabular}{|c|c|c|c|c|c|}
\hline 3 & Pavegen tiles & $\begin{array}{l}\text { V3 Tile, } 50 \mathrm{~cm} \\
\text { each edge }\end{array}$ & $\begin{array}{l}5 \text { Watts continuous power } \\
\text { from footsteps }\end{array}$ & $395 \$$ & 20 years \\
\hline 4 & Sound Power & $50 \times 50 \mathrm{~cm}$ & $0.1 \mathrm{~W}$ per 2 steps & $270.9 \$$ & 20 years \\
\hline 5 & $\begin{array}{l}\text { PZT ceramic } \\
\text { (Lead Zirconate Titanate) }\end{array}$ & $\begin{array}{l}\text { Manufacturing in } \\
\text { a small size }\end{array}$ & $8.4 \mathrm{~mW}$ & $36.1 \$$ & 20 years \\
\hline 6 & $\begin{array}{l}\text { hybrid energy floor - } \\
\text { combines human power } \\
\text { with solar energy }\end{array}$ & $\begin{array}{l}75 \times 75 \mathrm{~cm} \text { tile } \\
\frac{\text { OR }}{200} \mathrm{~cm}\end{array}$ & $\begin{array}{l}\text { up to } 250 \mathrm{kWh} \text { per year, } \\
\text { per tile }\end{array}$ & $1,693 \$$ & 20 years \\
\hline 7 & $\begin{array}{l}\text { - PZT Nanofiber - } \\
\text { Nanogenerator } \\
\text { - PZT Textile } \\
\text { Nanogenerator }\end{array}$ & $\begin{array}{l}\text { Sheets The with } \\
\text { material used with } \\
\text { volume of } 0.2 \mathrm{~cm} 3\end{array}$ & $\begin{array}{c}6 \mathrm{~mW} / \mathrm{cm} 30.03 \mu \mathrm{W} \text { power } \\
\text { density up to } 2.4 \mu \mathrm{W} / \mathrm{cm} 3 \\
{[20]}\end{array}$ & & 20 years \\
\hline 8 & $\mathrm{ZnO}$ nanowire VINGs & $\begin{array}{c}5 \mathrm{pW} 11 \mathrm{~mW} / \mathrm{cm}^{2} \\
2.7 \mathrm{~mW} / \mathrm{cm}^{3}\end{array}$ & very economically & & 20 years \\
\hline 9 & BaTiO3 & $\sim 7 \mathrm{~mW} / \mathrm{cm}^{3}$ & \multicolumn{3}{|c|}{$\begin{array}{l}\text { available commercially at low cost and in a variety } \\
\text { of designs }\end{array}$} \\
\hline
\end{tabular}

There are different types of piezoelectric tiles as shown in table 1. In table 1, the research summarized the different types of piezoelectric tiles according to its technical specifications. The data collected in table 1 were summarized from the product specifications of international companies working in the field of piezoelectric tiles. Table 1 presents the properties of each type of piezoelectric tiles such as size of each tiles, energy produced from one tile, the initial cost of the tile and average lifespan.

As shown in table 1, "PZT ceramic" is the cheapest type of tiles which produce an average of $8.4 \mathrm{~mW}$ per tile. On the other hand, Sound Power produce only $0.1 \mathrm{~W}$ per 2 steps and its initial cost is almost 5 times more than "PZT Ceramic". Each type of piezoelectric tiles has a specific feature and form, some of them has already been used in existing interior projects while others are still under experimental process. Table 2 summarizes the uses and features, form, and implemented projects of each type of piezoelectric tiles. 
Table 2. Uses and features of Piezoelectric tiles.

\begin{tabular}{|c|c|}
\hline Company & Uses and features \\
\hline $\begin{array}{l}\text { 1. Waynergy } \\
\text { Floor }\end{array}$ & $\begin{array}{l}\text { - The output power consumed or stored. } \\
\text { - Can be used for indoor or outdoor uses. } \\
\text { - Using in lighting, traffic control gadgets supply } \\
\text { - High pedestrian areas, Security systems supply, crosswalks, walkways, and public } \\
\text { transport stations. }\end{array}$ \\
\hline $\begin{array}{l}\text { 2. Sustainable } \\
\text { Energy floor } \\
\text { (SEF) }\end{array}$ & $\begin{array}{l}\text { - Use to power road lights and signage. } \\
\text { - The tiles can be fully customized. } \\
\text { - Many projects used it. } \\
\text { - Used in pavements and high pedestrian regions as airplane terminals, sport fields, } \\
\text { shopping centers, railroad stations and office and condo squares }\end{array}$ \\
\hline 3. Pavegen tiles & $\begin{array}{l}\text { - Used in various sectors including train stations, shopping centers, airports and public } \\
\text { spaces. } \\
\text { - can improve data-driven smart cities } \\
\text { - Each tile is equipped with a wireless API that transmits real-time movement data } \\
\text { analytics whilst directly producing power when and where it is needed } \\
\text { - can power interactive messages, billboards and signage } \\
\text { - Able to connect to a range of mobile devices and building management systems. } \\
\text { - Footfall tracking \& Identifying Footfall hotspots }\end{array}$ \\
\hline $\begin{array}{l}\text { 4. (EAPs) } \\
\text { Electroactiv } \\
\text { e Polymers }\end{array}$ & $\begin{array}{l}\text { - Generally generated high voltages } \\
\text { - Sensor Network Technology, sensor matrix } \\
\text { - Pressure mapping in order to trigger a control, warning or alarm signal. }\end{array}$ \\
\hline $\begin{array}{l}\text { 5. Sound } \\
\text { Power }\end{array}$ & $\begin{array}{l}\text { - Power Sources for many applications. } \\
\text { - Utilized in the emergency stairs } \\
\text { - } 0.1 \text { watt of electricity when a person steps on them is enough to illuminate } 50 \text { to } 100 \\
\text { "Christmas-tree" LED lights wired to the tile. }\end{array}$ \\
\hline $\begin{array}{l}\text { 6. PZT ceramic } \\
\text { (Lead } \\
\text { zirconate } \\
\text { titanate) }\end{array}$ & $\begin{array}{l}\text { - Extremely brittle \& Manufacturing in a small size More expensive than PVDF } \\
\text { (next type) } \\
\text { - Ultra-efficient piezoelectric material that can convert up to } 80 \text { per cent of mechanical } \\
\text { energy to electricity. } \\
\text { - PZT is } 100 \text { times more efficient than quartz } \\
\text { - Higher piezoelectric voltage constant than PVDF } \\
\text { - Has more value of voltage conversion than PVDF }\end{array}$ \\
\hline
\end{tabular}




\begin{tabular}{|c|c|}
\hline $\begin{array}{l}\text { 7. Parquet } \\
\text { PVDF layers } \\
\text { (polyvinylid } \\
\text { ene fluoride) }\end{array}$ & $\begin{array}{l}\text { - Simple manufacturing process \& inexpensive } \\
\text { - Can be produced in a big sized foil material } \\
\text { - Very suitable to the application of mass production technologies } \\
\text { - Modules are characterized by a great flexibility } \\
\text { - Very robust, resistant and has the possibility to be created in almost any geometrical } \\
\text { size and shape } \\
\text { - The energy yield is increasing by the multiplication of the layers } \\
\text { - Lengthwise arrangement is more efficient } \\
\text { - Energy yield is increasing at higher loading forces and higher thicknesses of the } \\
\text { modules } \\
\text { - Energy harvesters of PVDF can be used to power small electrical loads or wireless } \\
\text { sensor system }\end{array}$ \\
\hline $\begin{array}{l}\text { 8. Drum } \\
\text { Harvesters - } \\
\text { Piezo buzzer }\end{array}$ & $\begin{array}{l}\text { - Generating low power } \\
\text { - Generate useful electrical energy which can be used to power microelectronic devices } \\
\text { like Bluetooth, GPS modules, microcontrollers and low power sensors using ambient } \\
\text { vibrations from various sources. } \\
\text { - The fabrication process of these drum harvesters is cheap, easy and fast } \\
\text { - Quite robust and as such may be embedded in a variety of structures, under floors, } \\
\text { roads, etc. }\end{array}$ \\
\hline $\begin{array}{l}\text { 9. POWERleap } \\
\text { PZT. }\end{array}$ & $\begin{array}{l}\text { - As people walk across it to light up the night-time pavement } \\
\text { - The system uses 2-inch by } 1 \text {-inch PZT plates with a brass reinforcement shim covered } \\
\text { in nickel electrodes for low current leakage } \\
\text { - When these plates generated power induced and stimulates momentary electrical } \\
\text { energy impulses used to light the LED's inside each tile. } \\
\text { - Generated power can be stored in a battery as DC power }\end{array}$ \\
\hline $\begin{array}{l}\text { 10. Hybrid } \\
\text { energy floor } \\
\text { (HEF) }\end{array}$ & $\begin{array}{l}\text { - Combines human power with solar energy } \\
\text { - Converts solar power and kinetic energy from human movement to electrical energy } \\
\text { - Designed for installation on commercial streets, public squares, parks and pavements } \\
\text { - It uses photovoltaic panels with CIS (Copper Indium Selenide) solar technology. } \\
\text { Main benefits of CIS solar technology are its excellent performance in shady areas } \\
\text { and its maximum energy production with minimum power use }\end{array}$ \\
\hline
\end{tabular}

Tables 1 and 2 analyze the different types of piezoelectric tiles; table 1 helps select the type of piezoelectric tiles according to the budget, energy production, cost and size, while table 2 presents the functional properties of piezoelectric tiles such as tiles shapes, materials, and configuration of each type.

\section{APPLING PIEZOELECTRIC TILES IN “SHOBRA EL-KHEMA” METRO STATION}

This research intends to study the efficiency of using piezoelectric tiles in public facilities such as metro station in developing countries. Tables $1 \& 2$ can be used as a framework or designing tool to choose the best type of piezoelectric tiles that can be used in metro stations. The empirical section in this manuscript was applied in one of the developing countries that suffer from shortage in the power supply and high carbon emission production such as Egypt. 
In Egypt, the transportation segment is in charge of around 28\% of the energy utilization, and around $25 \%$ of energy related $\mathrm{CO}_{2}$ emanations, and is the quickest rising cause of $\mathrm{CO}_{2}$ emissions in Egypt (Moussa et al., 2021). The presented research intends to benefit from the individual's movements inside public facilities such as metro station in generating electricity for the station. The research intends to replace the regular tiles with piezoelectric tiles in the station stairs, and in the entrances.

\section{Study Area}

The study area of this research is Shobra El-Khema metro station which is located in Cairo-Egypt as shown in figure 3, The coordinates of Shobra El-Khema metro station are 30.0898676 N 31.2575837 E. Shobra El-Khema metro station has been chosen to be the study area of this research because of the largest number of passengers and it is located in a vital region and surrounded by residential and commercial buildings. Egyptian passengers using this station frequently because of the services surrounding the station.

\section{Components of Shobra El-Khema Metro Station}

Shobra El-Khema station considered an underground metro station. It consists of three floors; the 3rd floor consists of admission rooms and mechanical rooms. The $2^{\text {nd }}$ floor is the most important floor where the passengers pass by every day; it contains the tickets offices, the entrances, and station exits, police rooms, security and supervisors' offices, toilets, and services, etc. as shown in figure 4 . Moreover, the $1^{\text {st }}$ floor is the metro railway floor. The ticket hall that is located in the $2^{\text {nd }}$ floor is the central area as shown in figure 4 .
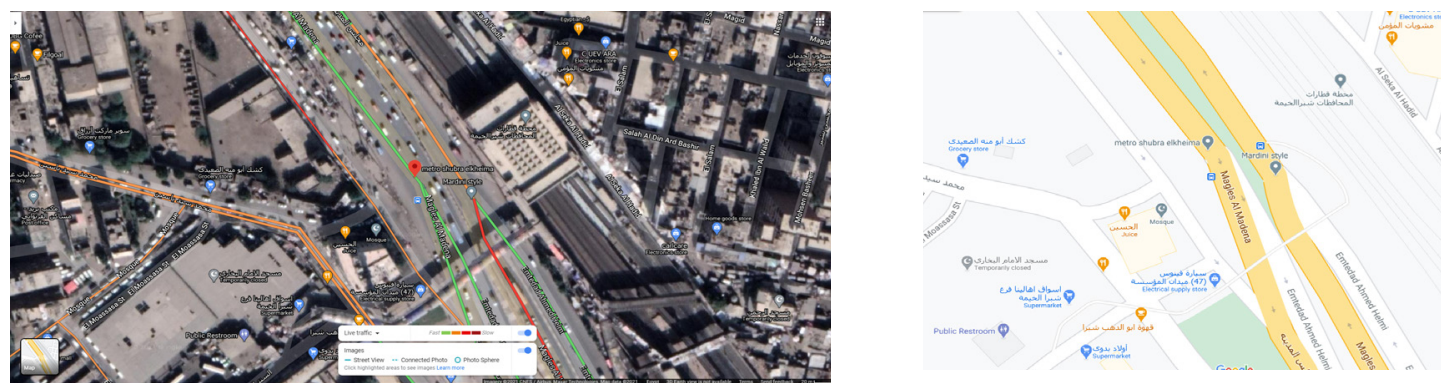

Figure 1. The location of Shobra El-Khema metro station, Source (google maps, 2019).

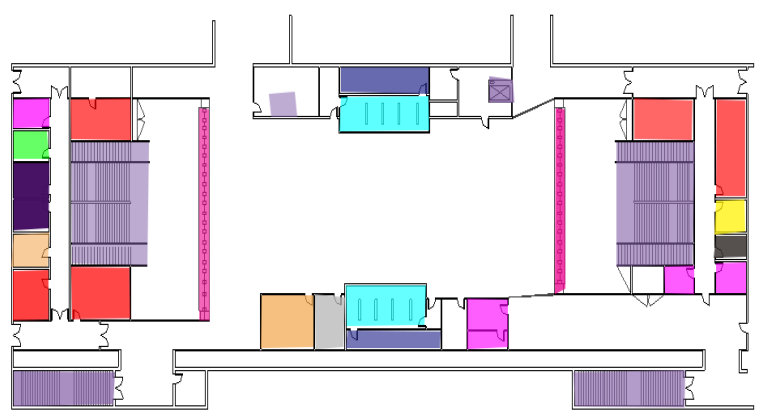

(1) Stairs and elevators

(2) Tickets offices

(3) Free public hall

(4) Two rows of turnstiles

(5) Storage rooms

(6) Police office

(7) Free rooms

(8) Supervisors office
(8)Engineer's office (9)Station's master's offices

(10)Cleaning room

(11)Garbage room

(12) Receipt and safe offices

(13) Secretary office

Figure 4. The plan Zoning of Shobra El-Khema metro station Ticket hall 


\section{Data Collection}

The data collected for this research were divided into three sections. Section one, is the station electricity consumption, this section provides the research with data related to the station electricity consumption. This step is needed to identify the number of piezoelectric tiles that should be installed for producing the amount of energy needed to power the station. Section two is the number of passengers, where the research identifies the population density inside the station. Section three is the pedestrian distribution density where the research identifies the most crowded areas inside the station.

\section{Section One: Electricity Consumption}

The research identified the average daily electricity consumption of Shobra El-Khema metro station which is approximately $3900 \mathrm{~kW}$ daily. The data was collected from the top manager of Shobra El-Khema metro station. The research needed to identify the electricity consumption of Shobra El-Khema metro station in order to compare the electricity consumption with the electricity production from using piezoelectric tiles to study the efficiency of using piezoelectric tiles in interior spaces which is the aim of this research.

\section{Section Two: Number of Passengers}

The amount of electricity generated from piezoelectric tiles will depend on the number of passengers passing through these tiles. The Egyptians prefer to use the metro as their main transportation system. The numbers of passengers in Shobra El-Khema metro station was collected from the ticket office inside the station. The distribution of passengers shows huge differences between working days, and weekends. The average number of daily passengers crossing the station is 49,000 person/day, knowing that the station is working almost 16 hours/ day.

\section{Section Three: Passengers Disruption Density}

The research used observational survey to determine the high density areas in Shobra El-Khema metro station to choose the best location for installing piezoelectric tiles.

According to the observational survey, the research highlighted the places with high population density inside the station which is in front of ticket offices, entrance and exit stairs, and security gates as shown in figure 5.

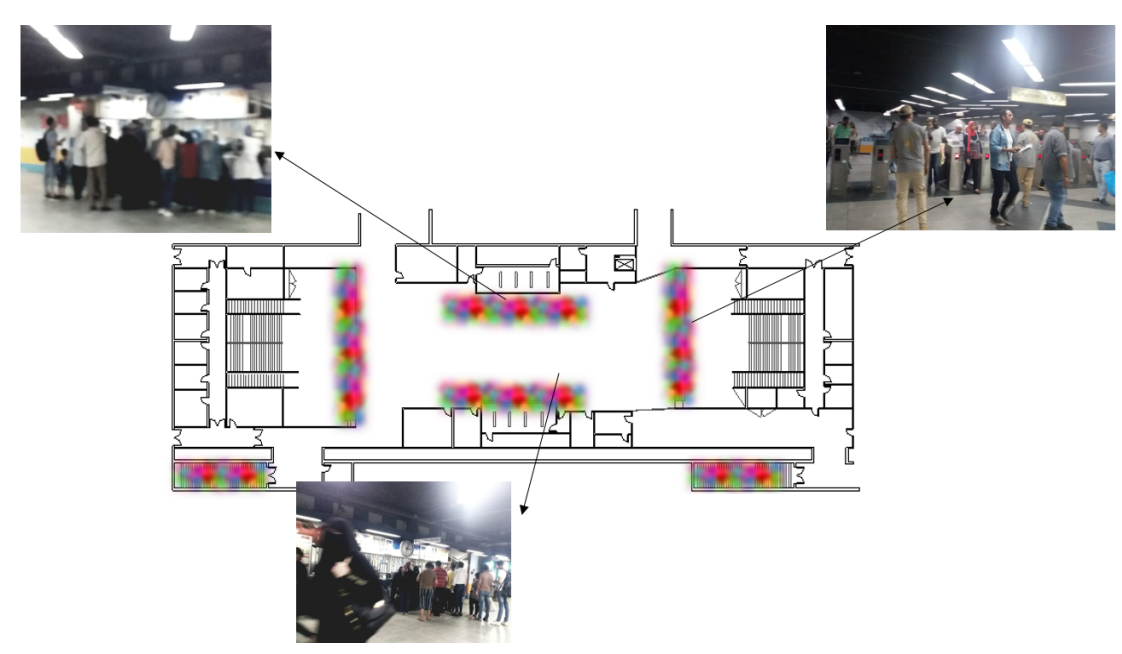

Figure 5. The most crowded areas inside Shobra El-Khema metro station 


\section{RESULTS}

This research intends to measure the efficiency of using piezoelectric tiles in electrify public facilities such as metro station using the proposed framework measuring the efficiency of using piezoelectric tiles will take place by implement piezoelectric tiles in Shobra El-Khema metro station. The results presented in this section will first choose the most suitable type of piezoelectric tiles from the framework presented in Tables 1 and 2. Then, it will calculate the energy produced from implementing piezoelectric tiles.

Referring to piezoelectric tiles framework which was presented previously in Tables $1 \& 2$, a comparison has been made between the properties of the existing tiles of Shobra El-Khema metro station and the properties of different types of piezoelectric tiles. It was notices that the best two types of piezoelectric tiles that can be used in Shobra El-Khema metro stations are Sustainable Energy Floor (SEF) and Waynergy. These two types share the same properties of the existing tiles of Shobra El-Khema metro station. According to the data collected from Shobra ElKhema metro station, the average energy daily consumption of the station is $3900 \mathrm{~kW} / \mathrm{day}$. The initial cost for buying $1 \mathrm{~kW}$ from the governmental to the public institution is 0.85 EGP. By assuming that all the passengers will pass on the same tiles, the numbers of daily passengers are 49,000 passengers.

Table 3 compared between the properties of Sustainable Energy Floor (SEF) and Waynergy types of piezoelectric tiles to choose the most suitable tile that could be installed in Shobra El-Khema metro station. The comparison intended to verify the number of tiles needed by both types to electrify Shobra El-Khema metro station.

As shown in table 3, ten tiles can generate the energy needed for electrifying the station using SEF piezoelectric tiles while Waynergy piezoelectric tiles can electrify the station by installing only seven tiles. On the other hand, the initial Cost of SEF is 165,000 EGP while the Waynergy tiles initial cost is 30,000 EGP. Waynergy tiles power generation is $10 \mathrm{~W}$ while Sustainable Energy Floor is $7 \mathrm{~W}$. This makes Waynergy produce more energy than the Sustainable Energy Floor (SEF). Moreover, the payback of Waynergy tiles is faster than Sustainable Energy Floor (SEF) tiles.

Depending on table 3, installing only 10 Sustainable Energy Floor (SEF) tiles will produce the energy need for electrifying the station. On the other hand, using only 7 Waynergy tiles will generate enough energy to satisfy the energy needed for electrifying the station. The presented research focuses on providing a tool (piezoelectric tiles framework) to simplify the design process on the architects and interior designer for designing energy generating tiles and replace it with regular tiles, the main challenge that will face the architects and the interior designers is to choose the most suitable location for installing the tiles. 
Table 3. Comparison between Sustainable Energy Floor (SEF) and Waynergy piezoelectric tiles.

\begin{tabular}{|c|c|c|}
\hline Properties & SEF & Waynergy \\
\hline $\begin{array}{l}\text { Power } \\
\text { generation/watt }\end{array}$ & 7 & 10 \\
\hline Unit and its price & 15000 EGP & 4000 EGP \\
\hline Size & $75 \times 75 \mathrm{~cm} \mathrm{Or} \quad 50 \times 50 \mathrm{~cm}$ & $40 \mathrm{~cm} \mathrm{x} 40 \mathrm{~cm}$ \\
\hline Materials & \multicolumn{2}{|c|}{$\begin{array}{c}\text { The tiles can be all kinds of material, which makes it possible to implement } \\
\text { them both inside and outside. }\end{array}$} \\
\hline Life span by years & 20 & 20 \\
\hline Number of tiles & \multicolumn{2}{|c|}{ Daily generation Capacity kW } \\
\hline 1 & 399 & 570 \\
\hline 2 & 798 & 1140 \\
\hline 3 & 1197 & 1710 \\
\hline 4 & 1596 & 2280 \\
\hline 5 & 1995 & 2850 \\
\hline 6 & 2394 & 3420 \\
\hline 7 & 2793 & 3990 \\
\hline 8 & 3192 & 4560 \\
\hline 9 & 3591 & 5130 \\
\hline 10 & 3990 & 5700 \\
\hline
\end{tabular}

In this case study, the main challenge that will face the architects and the interior designer is to choose a location where 49,000 passengers pass by every day, which is not the focus of this research. This research focuses on presenting the idea and not the application. The properties of installing 10 Sustainable Energy Floor (SEF) tiles and 7 Waynergy tiles in Shobra El-Khema metro station are presented in table 9. The properties were calculated according to the tile properties, which were presented previously in tables 1 and 2 in piezoelectric tiles framework section. 
Table 4. Properties for installing 10 Sustainable Energy Floor (SEF) tiles and 7 Waynergy tiles.

\begin{tabular}{|c|c|c|}
\hline Type & SEF & Waynergy \\
\hline Power generation/watt & $7 \mathrm{~W}=0.007 \mathrm{~kW}$ & $10 \mathrm{~W}=0.01 \mathrm{~kW}$ \\
\hline Number of tiles & 10 & 7 \\
\hline Initial Cost for installing one tile & 15,000 EGP & 4,000 EGP \\
\hline Initial Cost for installing tiles & $10 \times 15,000=150,000 \mathrm{EGP}$ & $7 \times 4,000=28,000 \mathrm{EGP}$ \\
\hline Daily Generation Capacity & $\begin{array}{c}(49,000 \times 0.07 \times 10)= \\
34,300 \mathrm{~kW} / \text { day }\end{array}$ & $\begin{array}{l}(49,000 \times 0.01 \times 7) \\
=3,430 \mathrm{~kW} / \text { day }\end{array}$ \\
\hline Lifespan & 20 years $x 365$ day $=7300$ day & 20 years $x 365$ day $=7300$ day \\
\hline Daily generation capacity kW & $3990 \mathrm{~kW} /$ day & $3990 \mathrm{~kW} /$ day \\
\hline $\begin{array}{l}\text { Cost for generating daily energy } \\
\text { from Piezoelectric tiles }\end{array}$ & $\begin{array}{l}150,000 / 7300 / 3990 \\
\quad=0.00515 \mathrm{EGP}\end{array}$ & $\begin{array}{c}28,000 / 7300 / 3990=0.000961 \\
\text { EGP }\end{array}$ \\
\hline Daily saving amount/ $1 \mathrm{~kW}$ & $0.85-0.00515=0.84485$ & $0.85-0.000961=0.8490$ \\
\hline Annual saving/ $1 \mathrm{~kW}$ & 308.37 EGP & 309.99 EGP \\
\hline $\begin{array}{l}\text { Annual saving for electrifying the } \\
\text { station using piezoelectric tiles }\end{array}$ & $\begin{array}{c}0.84485 \times 3990 \times 365= \\
1,230,397.3 \mathrm{EGP}\end{array}$ & $\begin{array}{c}0.8490 \times 3990 \times 365= \\
1,236,441.15 \mathrm{EGP}\end{array}$ \\
\hline Saving Percentage \% & $\begin{array}{c}100-((0.00515 / 0.85) \times 100) \\
=99.4 \%\end{array}$ & $\begin{array}{c}100-((0.000961 / 0.85) \times 100) \\
=99.88 \%\end{array}$ \\
\hline $\begin{array}{l}\text { Total saved amount through } 20 \\
\text { years (lifespan of tiles) }\end{array}$ & $\begin{array}{l}1,230,397.3 \times 20 \\
=24,607,946 \mathrm{EGP}\end{array}$ & $\begin{array}{l}1,236,441.15 \times 20 \\
=24,728,823 \mathrm{EGP}\end{array}$ \\
\hline
\end{tabular}

As presented in table 4, using 10 Sustainable Energy Floor (SEF) tiles will generate $3990 \mathrm{~kW} /$ day, while installing 7 Waynergy tiles will generate the same amount of Energy that has been generated by 10 tiles of Sustainable Energy Floor (SEF). The amount of energy saving using 10 Sustainable Energy Floor (SEF) tiles is almost $1,230,397.3 \mathrm{EGP} / \mathrm{year}$ with saving percentage of $99.4 \%$, while installing 7 Waynergy tiles will save annually $1,236,441.15$ EGP with saving percentage of $99.8 \%$.

According to the study, installing 7 Waynergy tiles is the best type of piezoelectric tiles for Shobra El-Khema metro station. By applying the Waynergy tiles to Shobra El-Khema metro station, the station will be a self-sustain project and the tiles can produce enough energy to electrify the metro station $100 \%$. The needed energy has been achieved in the two types, but it has been shown that depending on the space distribution of the high pedestrian spots 
analysis, metro ticket gates (turnstiles) have the peak number of pedestrians. The selected type is the Waynergy tiles as it has less cost and faster payback so it is the best solution to cover the energy needed with only 7 tiles.

\section{CONCLUSION}

Nowadays, clean and sustainable energy production is one of the most important problems facing the world. The increase in energy costs and decrease in the availability of nonrenewable energy sources have increased the energy problem globally. It turned out to be important to set up a new strategy to electrify the public facilities and public spaces based on renewable energy source instead of relying on national centralized power grid. Replacing the public facilities or public spaces tiles with piezoelectric tiles will help in decreasing the percentage of $\mathrm{CO}_{2}$ emissions globally, by decreasing the emissions produced from energy production. The world population growth rate is increasing daily, and using the world population growth rate in generating energy is a promising field for energy generation. Installing piezoelectric tiles which depends on human footprints will help in solving the energy production problem globally. Human movements will generate clean energy and reducing the carbon gas emissions, which is one of the main problems facing developing countries. Developing countries can start using the proposed technology to generate clean energy using their population density without harming the environment.

\section{REFERENCES}

Anton, S.R. \& Sodano, H.A. 2007. A review of power harvesting using piezoelectric materials (2003-2006). Smart Materials and Structures 16(3):R1-21.

Balouchi, F. 2013. Footfall Energy Harvesting: Footfall Energy Harvesting Conversion Mechanisms. Ph.D. Thesis, University of Hull.

Bischur, E. \& Schwesinger, N. 2012. Energy harvesting from floor using organic piezoelectric modules. Power Engineering and Automation Conference (PEAM). (Accessed 17 July 2019).

Elhalwagy, A.M. Ghoneem, M.Y.M. \& Elhadidi, M. 2017. Feasiability study for using piezoelectric energy harvesting floor in buildings' interior space. Energy Procedia 115:114-126.

Farahat, B.I. 2014. Piezoelectric materials "Potentials and Constrains "Upgrading Designs and Techniques". Conference: IICE2014 (The First Irbid International Engineering Conference). Irbid, Jordan. (Accessed 17 July 2019).

Hill, D. Agarwal, A. \& Tong, N. 2014. Assessment of Piezoelectric Materials for Roadway Energy Harvesting "Cost of Energy and Demonstration Roadmap". California: DNV KEMA Energy \& Sustainability, pp.1-93.

Kachapi, S.H.H. 2020. Free vibration analysis of piezoelectric cylindrical nanoshell: nonlocal and surface elasticity effects. WSEAS Transactions on Systems and Control, 15: 141-165.

Kachapi, S.H.H. 2019. Nonclassical vibration analysis of piezoelectric nanosensor conveying viscous fluid. WSEAS Transactions on Applied and Theoretical Mechanics, 14: 252-271

Mak, K.H. McWilliam, S. Popov, A.A. \& Fox, C.H.J. 2011. Performance of a cantilever piezoelectric energy harvester impacting a bump stop. Journal of Sound and Vibration 330: 6184-6202. Available at: https://doi.org/10.1016/j.jsv.2011.07.008

Mishra, R. Jain, S. Durgaprasad, C. \& Sahu, S. 2015. Vibration Energy Harvesting Using Drum Harvesters. International Journal of Applied Engineering Research 10(14): 34995-35001. (Accessed 17 July 2019).

Moussa, R.R. \& Mahmoud, A.H. 2017. Energy-scape Elements: An Approach on Integrating Landscape Elements with Renewable Energy Devices. Journal of Cleaner Production 153: 114-130.

Moussa, R.R. 2018. The role of energy-scape elements in creating sustainable economic project in Egyptian parks. Ain Shams Engineering Journal 9(4): 3045-3053. 
Moussa, R.R. 2019. The Effect of Piezo-Bumps on Energy Generation and Reduction of the Global Carbon Emissions. WSEAS Transactions on Environment and Development 15(46): 430-437.

Moussa, R.R. 2020. Installing Piezoelectric tiles in Children Outdoor Playing areas to Create Clean \& Healthy Environment; Case Study of El-Shams Sporting Club, Cairo_Egypt. WSEAS Transactions on Environment and Development, 16; 471-479. Retrieved from: https://doi.org/10.37394/232015.2020.16.48.

Moussa, R.R., Mahmoud, A.H., and Hatem, T.M. 2020. A digital tool for integrating renewable energy devices within landscape elements: Energy-scape online application. Journal of Cleaner Production, 254; 1-13.

Moussa, R.R., Mansour, M.M.M. and Yossif, N.M. 2021. Statistic Equation to Estimate the Amount of $\mathrm{CO}_{2}$ Emission Produced From High Traffic Density Roads. WSEAS Transactions on Power Systems, 16; 78-86. Retrieved from: https://doi.org/10.37394/232016.2021.16.8

Omega. 2016. Available at: http://www.omega.com/pptst/DLC101.html (Accessed 10 April 2019).

Pavegen, 2019. Smart cities retail technologies dynamic learning brand activations. Available at: http://www.pavegen.com/ (Accessed 17 July 2019).

Rahman, T., Sakir, S.R. \& Onna, S.D. 2012. Design of an efficient energy harvester from ambient vibration. Department of Electrical and Electronic Engineering, (EEE) BRAC University, Dhaka, Bangladesh 1-77. Available http://dspace.bracu.ac.bd/xmlui/bitstream/handle/10361/1832/Design\%20of\%20an\%20efficient\%20energy $\% 20$ harvester.pdf? sequence $=1 \&$ isAllowed $=y$, (Accessed 8 July 2019).

Rawat, M.S. \& Vadhera, S. 2019. A Comprehensive Review on Impact of Wind and Solar Photovoltaic Energy Sources on Voltage Stability of Power Grid. Journal of Engineering research, 7(4); 178-202. Available at: 7121-Article Text-29247-1-10-20191120.pdf

Rodrigues, João André da Costa Coimbra. 2011. Waynergy: The way for energy harvesting: Business model design. Diss. NSBE-UNL. Available at: http://utenportugal.org/wp-content/uploads/Waynergy-The-way-forenergy-harvesting.pdf, (Accessed 12 May 2019).

Shreeshayana, R., Raghavendra, L. \& Manjunath V.G. 2017. Piezoelectric Energy Harvesting using PZT in Floor Tile Design. International Journal of Advanced Research in Electrical, Electronics and Instrumentation Engineering 6(12): 8872-8879.

Shwehdi, M.H., Rajamohamed, S., Smadi, A.A., Bouzguenda, M., Alnaim, A.A. \& Fortea, S. 2015. Energy savings approaches of buildings in hot-arid region, Saudi Arabia: case study. Journal of Engineering research, 3(1); 178-202. Available at: https://kuwaitjournals.org/jer/index.php/JER/article/download/377/48

Solban, M.M. \& Moussa, R.R. 2019. Piezoelectric Tiles Is a Sustainable Approach for Designing Interior Spaces and Creating Self-Sustain Projects. (November, 28 -30). (BSCairo2019) Simulation for a Sustainable Built Environment, Cairo_Egypt. IOP Conf. Series: Earth and Environmental Science 397- 012020.

Starner, T. \& Paradiso, J.A. 2003. Human generated power for mobile electronics. Low Power Electronics Design. CRC Press 45: 1-30.

Sunithamani, S., Lakshmi, P. \& EBA, F. 2017. Design of Piezoelectric Energy Harvester with Controlled and Regulated Output Voltage: Simulation Study. WSEAS TRANSACTIONS on POWER SYSTEMS, 12: 6372.

Vinod, A. \& Sinha, A.K. 2019. Estimation of parameters for one diode solar PV cell using grey wolf optimizer to obtain exact V-I characteristics. Journal of Engineering research, 7(1); 1-19. Available at: 4223-Article Text-25632-1-10-20190506.pdf 